\title{
Micose fungoide: relato de caso tratado com radioterapia *
}

\author{
Mycosis fungoides: case report treated with radiotherapy
}

\author{
Gustavo Nader Marta ${ }^{1}$ \\ Stéfani Bertolucci Estevam Ferreira ${ }^{2}$ \\ Cecília Maria Kalil Haddad ${ }^{4}$
}

\author{
Carolina Bueno de Gouvêa ${ }^{2}$ \\ Samir Abdallah Hanna ${ }^{3}$ \\ João Luis Fernandes da Silva ${ }^{5}$
}

\begin{abstract}
Mycosis fungoides is a rare type of non-Hodgkin's lymphoma of $\mathrm{T}$ cells that primarily affects the skin. It is characterized by the presence of erythematous plaques that evolve into ulcerated lesions, tumors throughout the skin or even bone marrow infiltration in advanced stages. Chemotherapy and topical steroids, phototherapy and radiotherapy are treatment options for early cases. This study reports the case of patient with multiple tumor lesions in the skin already biopsied with diagnosis of mycosis fungoides. The patient was refractory to both treatments with topical chemotherapy and phototherapy. It was then indicated total skin irradiation with electrons.

Keywords: Lymphoma, T-Cell, cutaneous; Mycosis fungoides; Radiotherapy

Resumo: Micose fungoide é um tipo de linfoma não Hodgkin de células T raro que acomete primariamente a pele. Caracteriza-se pela presença de placas eritematosas que evoluem para lesões ulceradas, tumores em toda a pele ou ainda infiltração de medula óssea em estágios avançados. Como opção de tratamento para os casos iniciais, tem-se quimioterapia e corticoterapia tópica, fototerapia e radioterapia. Este estudo relata o caso de um doente com múltiplas lesões tumorais na pele já biopsiadas com diagnóstico de micose fungoide. O paciente foi refratário ao tratamento com quimioterapia tópica e fototerapia, sendo então indicada irradiação total da pele com elétrons.

Palavras-chave: Linfoma cutâneo de células T; Micose fungoide; Radioterapia
\end{abstract}

\section{INTRODUCTION}

Mycosis fungoides (MF) is the most common type of cutaneous lymphoma of T- cells included in the classification of non Hodgkin limphoma ${ }^{1}$. Histologically, MF is characterized by the presence of Sézary-Lutzner cells (T helper cells), which form clusters in the superficial dermis and invade the epidermis in small cell groups. ${ }^{2}$ Diagnosis shows that there is predominance in patients who are between 55-60 years of age being more common in male patients (1,6-2 men: 1 women) and with rare incidence in childhood and young adults ${ }^{3}$. Initially, lesions have a generic feature, similar to inflammatory dermatoses affecting the skin in areas not exposed to the sun such as pelvic girdle, buttocks, lower trunk, groin, axillae and breasts. ${ }^{4}$ With the development of the disease lesions become infiltrated, as elevated erythematous plaques or reddish-brown, with well defined borders and eccentric contours. Etiological evidence were not yet proven but infectious agents, occupational exposure and genetic mutations have been evaluated as possible carcinogens ${ }^{5}$. The gold standard for the diagnosis of MF is histopathology that can be complemented by clinical, molecular and immunopathologic presentation. For staging it is taken into account the

\footnotetext{
Received on 24.11.2009.

Approved by the Advisory Board and accepted for publication on 13.05.10.

* Work carried out at the Department of Radiotherapy of the Oncology Center from the Sírio Libanês Hospital - São Paulo (SP), Brazil.

Conflict of interest: None / Conflito Interesses: Nenbum

Financial funding: None / Suporte Financeiro: Nenbum

Medical Residency -Radiotherapy Resident physician at the Oncology Center from the Sirio Libanês Hospital - São Paulo (SP), Brazil.

Graduation - Medical student from the State University of Londrina (UEL) - Londrina (PR), Brazil.

Specialist - Assistant doctor and preceptor of the Department of Radiotherapy at the Oncology Center from the Sirio Libanês Hospital - São Paulo (SP), Brazil.

Specialist - Physicist responsible for the Oncology Service at the Sírio Libanês Hospital - São Paulo (SP), Brazil.

Specialist - Medical coordinator of the Department of Radiotherapy at the Oncology Center from the Sírio Libanês Hospital - São Paulo (SP), Brazil. 
evolution of the disease in the skin (T), the lymph node status $(\mathrm{N})$, visceral $(\mathrm{M})$ and blood involvements (B)?. Options for treatment in early stage are topical chemotherapy (Nitrogen mustard or carmustine), topical corticosteroids, phototherapy or radiotherapy (x-ray or electrons) localized or on the whole body surface. In later stages, it can be tried total skin irradiation as a form of curative or palliative treatment. ${ }^{6}$ Prognosis for MF is related to the staging, mainly concerning the extension and skin involvement type and the presence or absence of extra cutaneous disease.

\section{CASE REPORT}

Male patient, aged 56, Caucasian, married. $\mathrm{He}$ had been diagnosed with MF since 2002, was referred to the Radiotherapy Department of the Oncology Center at the Sirio-Libanês Hospital on 15/07/2009 by having disease refractory to prior instituted therapies with phototherapy, Nitrogen mustard and topical corticosteroids. He complained of multiple cutaneous lesions and moderate to intense itching. Clinical examination showed maculopapular and tumor lesions distributed all over the body surface without palpable lymphadenopathy. There was a single ulceratedd lesion on the buttock with approximately $4 \mathrm{~cm}$ in diameter (Figure 1). Biopsy of skin lesion in the right arm was performed and it demonstrated that it was neoplasm of $\mathrm{T}$ cells of difficult classification, consistent with peripheral T- cell lymphoma without other specification. The tumor was composed predominantly of big cells, with moderate component of eosinophils and other cell types. Neoplasia widely infiltrated the dermis, skin appendages and vascular structures. Himuno-histochemical study showed pos- itivity for CD45 and CD43. CT (computed tomography) of the thorax and abdomen did not show evidence of visceral involvement. Blood test showed absence of atypical cells in the circulation. (staging IIB).

Radiotherapy with electrons of all skin was the proposed treatment. It was used technique with distance focus-skin of 100 to $140 \mathrm{~cm}$ recquiring personal dosimetry and calculation of specific dose-monitor for each situation. It was used energy of $6 \mathrm{MeV}$ with 16 fields of previous treatment and 16 fields of subsequent treatment. The total dose was $30 \mathrm{~Gy}$ all over the body surface with boost of $6 \mathrm{~Gy}$ in regions with gross tumor. The patient was treated for 4 days per week ( 2 applications in the anterior region and 2 in the posterior region) with daily dose/fraction of 200cGy continuously Eyes and lips were protected with lead plates since the beginning of radiotherapy. At the end tof the treatment the patient presented erythema, skin peeling without ulceration, xeroderma and alopecia .

After 2 months of evolution (Figure 2), there was complete response and the patient has no clinical evidence of recurrence. The ulcerated lesion on the buttock showed clear involution and presented itself in a healing stage.

\section{DISCUSSION}

Despite being the most common type of cutaneous lymphoma of $\mathrm{T}$ cells, MF is a rare disease, with incidence of 0,5 cases per 100.000 people per year. Furks et $\mathrm{al}^{8}$ showed that the average lengh of time between the appearance of the lesion and the pathological diagnosis of MF is 8 to 10 years.

For a long time the only options for treatment

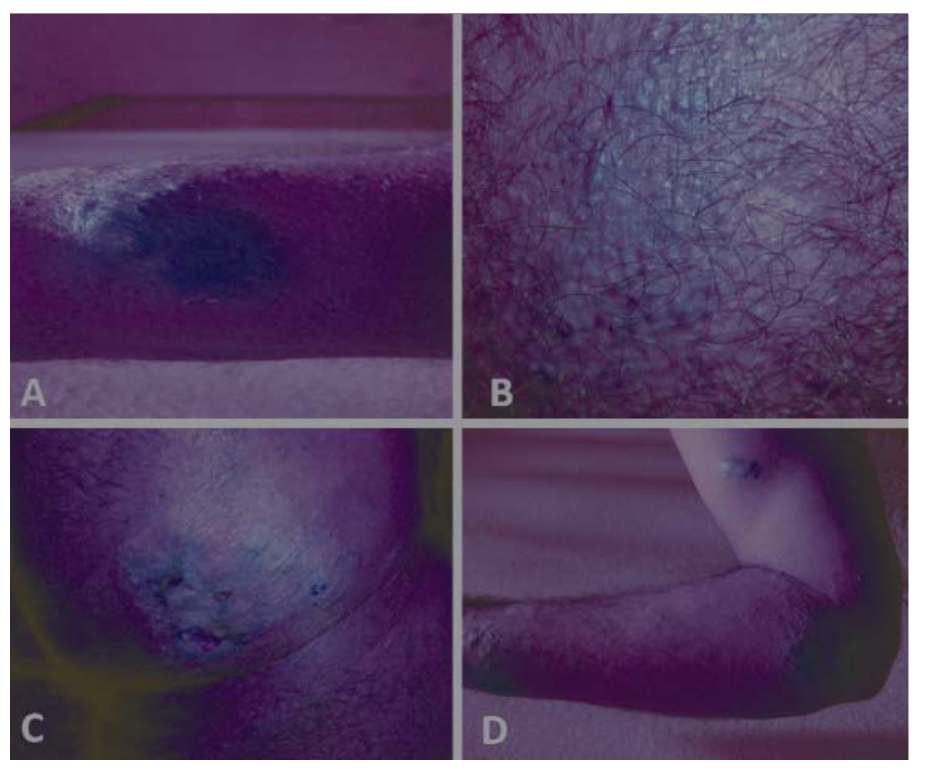

Figure 1: A: Maculopapular lesion on the left wrist; B: Maculopapular lesion on the posterior chest area C: Ulcerated lesion on buttock; D: Tumor lesions on the right arm 

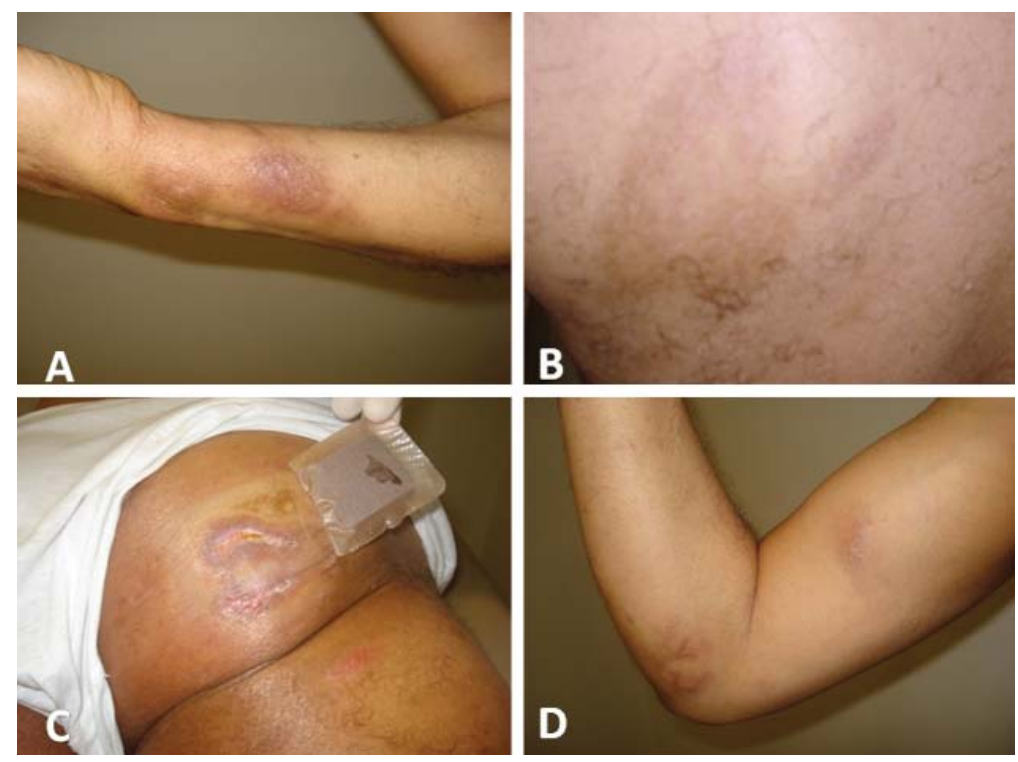

Figure 2: Appearance of lesions after 2months of treatment : A: Left wrist; B: Posterior chest; C: Buttock ; D: Right arm

of MF were steroids, phototherapy and topical chemotherapy (carmustine and Nitrogen mustarde), which showed satisfactory results when used to treat the disease in early stage. However, monotherapy or the association of such therapies are, many times, insufficient to control the disease and it is observed high levels of recurrence. ${ }^{9,10}$

Radiotherapy with electrons of all skin is normally used in patients with history of quick progression of the disease or when there is interruption of treatment after initial topical approach. Complete response rates after 3 months of treatment vary from 80 to $97 \%^{11}$. Adjuvancy with phototherapy or topical chemotherapy can be used to consolidate the treatment. ${ }^{12}$.

The most common side effects after treatment are erythema, skin peeling, cutaneous ulceration, alopecia, nail fall and xeroderma that are normally well tolerated by patients. Chronically, it is possible the appearance of telangiectasia and nail dystrophy. It has also being reported the appearance of a second squamous proliferative skin cancer ${ }^{13,14}$, as well as in any other situation in which it has been used ionizing radiation

The most important prognostic factor for MF is the staging in which it is evaluated the evolution of the disease in the skin $(\mathrm{T})$, the lymph node status $(\mathrm{N})$, visceral (M) and blood involvements (B). The presence of extra cutaneous disease is rare and occurs preferably in the lungs, oral cavity and nervous central system. ${ }^{15}$. Sézary cells are atypical, mononuclear, with cerebriform nuclei. Their presence in more than $5 \%$ in the peripheral circulation is used as criteria for the diagnosis of Sérazy syndrome being a leukemic variant of the disease that, in general, presents itself from the beginning with erythroderma and evolves with diffuse alopecia, palmo plantar hyperkeratosis and diffuse lymph node involvement. ${ }^{16}$.

The majority of patients with tumor involvement or erytroderma die from causes related to MF disease such as reccurent infections, sepsis secondary to cutaneous disease and organ failure due to visceral involvement. 


\section{REFERENCES}

1. Olsen E, Vonderheid E, Pimpinelli N, Willemze R, Kim Y, Knobler R, et al. Revisions to the staging and classification of mycosis fungoides and Sezary syndrome: a proposal of the International Society for Cutaneous Lymphomas (ISCL) and the cutaneous lymphoma task force of the European Organization of Research and Treatment of cancer (EORTC). Blood. 2007;110:1713-22.

2. Pimpinelli N, Olsen EA, Santucci M, Vonderheid E, Haeffner AC, Stevens S, et al. Defining early mycosis fungoides. J Am Acad Dermatol. 2005;53:1053-63.

3. Gardner JM, Evans KG, Musiek A, Rook AH, Kim EJ. Update on treatment of cutaneous T-cell lymphoma. Curr Opin Oncol. 2009;21:131-7.

4. Latkowski JA, Heald PW. Cutaneous T cell lymphomas. In: Freedberg IM, Eisen AZ, Wolff K, Austen KF, Goldsmith LA, Katz SI, editors. Fitzpatrick's dermatology in general medicine. New York: McGraw-Hill; 2003. p.1537-58.

5. Morales Suárez-Varela MM, Llopis González A, Marquina Vila A, Bell J. Mycosis fungoides: review of epidemiological observations. Dermatology. 2000;201:21-8.

6. Whittaker SJ, Marsden JR, Spittle M, Russell Jones R; British Association of Dermatologists; U.K. Cutaneous Lymphoma Group. Joint British Association of dermatologists and UK Cutaneous Lymphoma Group guidelines for the management of primary cutaneous T-cell lymphomas. $\mathrm{Br} \mathrm{J}$ Dermatol. 2003:149:1095-107.

7. Weinstock MA, Horn JW. Mycosis fungoides in the United States: increasing incidence and descriptive epidemiology. JAMA. 1988;260:42-6.

8. Fuks Z, Bagshaw MA, Farber EM. Prognostic signs and management of mycosis fungoides. Cancer. 1973;32:1385 -95.

9. Vonderheid EC, Tan ET, Kantor AF, Shrager L, Micaily B, Van Scott EJ. Long-term efficacy, curative potential, and carcinogenicity of topical mechlorethamine chemotherapy in cutaneous T cell lymphoma. J Am Acad Dermatol. 1989;20:416-28.

10. Duarte I, Buense R, Aoki S. Micose fungóide: estudo epidemiológico de 17 casos e avaliação da resposta terapêutica à PUVA (radiação ultravioleta A associada ao 8- metoxipsoraleno oral). An. Bras Dermatol. 2006;81:40-5.
11. Le Bourgeois JP, Haddad E, Marinello G, Marin L, Mazeron JJ, Ganem G. The indications for total cutaneous electron beam radiation herapy of mycosis fungoides. Int J Radiat Oncol Biol Phys. 1987;13:189-93.

12. Micaily B, Campbell O, Moser C, Vonderheid EC, Brady LW. Total skin electron beam and total nodal irradiation of cutaneous T-cell lymphoma. Int J Radiat. Oncol. Biol Phys. 1991;20:809-13.

13. Bunn PA, Lamberg SI. Report of the Committee on Staging and Classification of Cutaneous T-Cell Lymphomas. Cancer Treat. Rep. 1979:63:725-72.

14. Vonderheid EC. Topical mechlorethamine chemotherapy: considerations on its use in mycosis fungoides. Int J Dermatol. 1984:23:180-6.

15. Cox D. Regression models and life-tables. J R Stat Soc B. 1972;34:187-220.

16. Edelson RL. Cutaneous T-cell lymphoma: Mycosis fungoides, Sézary syndrome and other variants. J Am Acad Dermatol. 1980;2:89-106.

How to cite this article/Como citar este artigo: Marta GN, Gouvêa CB, Ferreira SBE, Hanna SA, Haddad CMK, da Silva JLF. Mycosis fungoides: case report treated with radiotherapy. An Bras Dermatol. 2011;86(3):561-4. 